\title{
On the Contribution of Baseball to American
}

\section{Legal Theory}

\author{
Charles Yablon ${ }^{\dagger}$
}

Americans are great lovers of games. We love to play them, to watch them, to argue about them, and to bet money on them. We use the term "game" to denote not only trivial and unimportant pastimes, but some of the most significant events in our personal and professional lives. As Wittgenstein so playfully pointed out, the term "game" has no fixed and definite meaning.' It can refer to anything from a ball bouncing against a wall to multimillion dollar corporate takeovers ${ }^{2}$ to the most intimate of human relationships."

Certain games are deeply embedded in American culture and psychology. American football, for example, is little understood by the rest of the world. but has acquired a quasi-religious significance in the United States as the ritual through which we observe some of our most important national holidays." Although basketball, by contrast, has achieved worldwide popularity, it was invented in the United States, ${ }^{5}$ and American superiority in the sport recently was demonstrated by the performance of the United States' "Dream Team" in the Barcelona Olympics and the so-called "Dream Team II" at the 1994 world basketball championships in Toronto. These teams dominated their opponents not just on the basketball court, but, more important, in the intense international competition for lucrative product endorsements.

But one game is more intimately linked to American society and American self-image than any other. Its rules and strategies are avidly studied by millions

$\div$ Professor of Law, Benjamin N. Cardozo School of Law. Yeshuva Unuersily Thus paper was presented, among other places, at the Sixteenth World Congress in Philosophy of Law and Social Philosophy in Reykjavik, Iceland. They didn't get it. Thanks to David Carison. Stewart Sterk, and Jark Williams, who did.

1. Ludwig Wittgenstein, Philosophical investigations 960 (G.E.M Anscombe trans. $3 d$ ed 1958).

2. See, e.g., John Brooks, The TAKeOver GAME (1987): George Getschou \& Bnan Burrough. Pickens, Acting Bitter. Finds Takeover Game Isn't Much Fun Now. WaLL ST J. Apr 5. 1988. al Al. Jeffrey Sheban, Takeover Game in Britain Is Played With Rules Thar Would Hall U.S. Deals. W +L1. ST J., Nov. 3, 1989, at B5; Caleb Solomon, In the Takeover Ganse. Hidden Waste Dumps Haunt Buser and Seller, Wall ST. J., Apr. 2. 1990. at Al.

3. See Yumiko Ono. Outnumbered by Men. Tokyo Women Gan Upper Hand in Watmg Game. Aslx) WALl ST. J. WKLY., Oct. 14, 1991, at 10; see also The CRYING GAME (Mfiramax Films 1992)

4. Thanksgiving. New Year's Day, and Super Bowl Sunday.

5. Its inventor, however, was a Canadian. See Nathaniel Strohl. Dr. Natsmuth. Spokts llll STRATED. Apr. 5, 1993, at 4 (letter to the editor). 
of Americans. It is the subject of intense media interest. Its most successful practitioners earn many millions of dollars. The outcome of a single contest can rivet the attention of whole cities, indeed, the entire nation. It can even cause riots to break out. It is a pastime Americans indulge in more frequently than any other people on earth. That game, of course, is litigation.

Americans also watch a lot of baseball. ${ }^{6}$

This Essay seeks to analyze the importance of baseball to American legal theory. This Essay does not discuss the law as it applies to baseball, although the scholarly law journals are replete with learned analyses of the baseball exemption to the antitrust laws, ${ }^{7}$ the rights of free agency under collective bargaining agreements, ${ }^{8}$ and even the tort liability of major league baseball to spectators beaned by hard-hit foul balls. ${ }^{9}$ It is not even about the infamous George Brett pine tar incident, in which an umpire's ruling disqualifying a hit from an overtarred bat was reversed by the President of the American League, ${ }^{10}$ nor about Justice Blackmun's list of eighty-eight of the most memorable baseball players, which appeared in the first part of the Supreme Court's decision in Flood v. Kuhn ${ }^{11}$ (a section that Chief Justice Burger and Justice White declined to join). ${ }^{12}$

No, this Essay deals with the contribution of baseball to what is commonly referred to as jurisprudence or philosophy of law. It seeks to demonstrate how

6. At least, they do between baseball strikes.

7. See, e.g., Robert G. Berger, After the Strikes: A Reexamination of Professional Baseball's Exemption from the Antitrust Laws, 45 U. PITT. L. REV. 209 (1983); Lee Goldman, Sports, Antitrust, and the Single Entity Theory, 63 TUL. L. REv. 751 (1989); Gary R. Roberts, Reconciling Federal Labor and Antitrust Policy: The Special Case of Sports League Labor Market Restraints, 75 GEO. L.J. 19 (1986); Thane N. Rosenbaum, The Antitrust Implications of Professional Sports Leagues Revisited: Emerging Trends in the Modern Era, 41 U. MiAMI L. REv. 729 (1987); Stephen F. Ross, Monopoly Sporis Leagues, 73 MINN. L. REV. 643 (1989).

8. See, e.g., Ethan Lock, The Scope of the Labor Exemption in Professional Sports, 1989 DUKE L.J. 339; Robert A. McCormick, Baseball's Third Strike: The Triumph of Collective Bargaining in Professional Baseball, 35 VAND. L. REV. 1131 (1982); Note, Releasing Superstars from Peonage: Union Consent and the Nonstatutory Labor Exemption, 104 HARV. L. REV. 874 (1991); Michael J. Cozzillio, From the Lamd of Bondage: The Greening of Major League Baseball Players and The Major League Baseball Players Association, 41 CATH. U. L. REv. 117 (1991) (reviewing Marvin Miller, A WhOle Different BALLGAME: THE SPORT AND BUSINESS OF BASEBALL (1991)).

9. See RESTATEMENT (SECOND) OF TORTS $\$ 496 \mathrm{C} \mathrm{cmt.} \mathrm{g,} \mathrm{illus.} 4$ (1965); 4 FOWLER V, HARPER ET AL., THE LAW OF TORTS $\S 21.5$, at 238-41, 243-44 (2d ed. 1986); Donald P. Judges, Of Rocks and Hard Places: The Value of Risk Choice, 42 EMORY L.J. 1, 116-17 (1993); Kenneth W. Simons, Assumption of Risk and Consent in the Law of Torts: A Theory of Full Preference, 67 B.U. L. REv. 213, 223, 261, 279 (1987); Matthew J. Toddy, Case Comment, Assumption of Risk Merged with Contributory Negligence: Anderson v. Ceccardi, 45 OHIO ST. L.J. 1059, 1062-63 (1984).

10. See Joseph Lukinsky, Law in Education: A Reminiscence with Some Footnotes to Robert Cover's Nomos and Narrative, 96 YALE L.J. 1836, 1855-56 (1987) ("The arguments fconcerning the pine tar incident] constituted perhaps the most widespread popular legal debate in American history."); see also Christopher H. Clancy \& Jonathan A. Weiss, A Pine Tar Gloss on Quasi-Legal Images, 5 CARDozo L. REv. 411 (1984); Donald J. Rapson, A "Home Run" Application of Established Principles of Statutory Construction: U.C.C. Analogies, 5 CARDozo L. REv. 441, 441-44 (1984); Jared T. Finkclstein, Commentary, In re Brett: The Sticky Problem of Statutory Construction, 52 FORDHAM L. REV, 430 (1983).

11. 407 U.S. 258, 262-63 (1972); see also BOB WOODWARD \& SCOTT ARMSTRONG, THE BRETHREN: INSIDE THE SUPREME COURT 189-92 (1979) (describing Justice Blackmun's principles for inclusion in list).

12. Flood, 407 U.S. at 285-86 (Burger, C.J., concurring). 
recent advances in American legal theory have been brought about by the salutary influence of baseball rules and baseball traditions on the thought processes of legal scholars. I realize the claim is a radical one. Not all legal scholars are baseball fanatics. I myself am only sort of a fair-weather Mets fan. ${ }^{13}$ But as the contemporary academic world amply demonstrates, lack of actual knowledge of the subject matter is no impediment to serious scholarly work.

My thesis is a simple one, so I will attempt to state it with as much complexity as possible. First, all American lawyers are enmeshed in the normative boundaries of two incompatible legal systems: the so-called "real" legal system, which they tediously learn through years of law school, and the legal system of baseball, which they pick up effortlessly from playgrounds, sports pages, and television. Second, baseball's legal system is clearly and demonstrably superior to the real legal system. Third, most of the advances in American legal theory have come from lawyers trying to figure out why the real legal system can't be more like baseball. ${ }^{14}$

I will not bother to defend the proposition that Americans are familiar with the normative structure of baseball. Any American determined not to learn the fundamentals of baseball would have to make a lifelong effort to avoid all newspapers, television, playgrounds, and taverns, as well as certain forms of bubble gum and selected boxes of breakfast cereal. Anyone who chose to follow this unlikely (but oddly appealing) regimen would still likely wind up knowing what it means, in the American idiom, to "strike out," "get to first base," and "play in the big leagues."

The point of this Essay, then, is (1) to show that the normative structure of baseball is indeed superior to that of law, and (2) to describe how the attempts of various scholars to deal with that superiority have contributed to the development of American legal theory.

\section{GETTING TO FIRST: THE NORMATIVE SUPERIORITY OF BASEBALL TO LAW}

To begin, we must uncover the hidden history of games and the law. Lawyers play games. Judges play games. But precisely what game are they playing? Although the historical record remains obscure, and much of the relevant evidence has been suppressed, it appears that through much of early legal history, the game they were playing was dice.

13. That is, I only follow them closely when they are winning. Needless to say. l've had a lot of free time during baseball season in recent years-which explanns a thing or two about this Essay

14. As the recent baseball strike has shown, when baseball is involved in real legal disputes "I turns out to be just as messy and ambiguous as the rest of modem life. with no clear winners and no one wanting to cheer for either side. 
Consider that great legal theorist, François Rabelais, recounting the testimony of Judge Bridlegoose, an innovative sixteenth-century jurist who was often faced with the problem of conflicting or vague precedents that modern legal academics have come to characterize as the "indeterminacy of the law."15 Bridlegoose subjected his cases to careful analysis. He quite literally weighed the pleadings and papers in the case before him. If the papers were voluminous, and the legal issues accordingly weighty, he resolved them by rolling his little dice. In simpler cases, with shorter pleadings, he used his big dice. $^{16}$ Although Bridlegoose's contemporaries questioned some of his methods, he justified them by pointing out that although his decisions were frequently appealed, none had ever been reversed. ${ }^{17}$

Modern judges, however, have tended to reject the Bridlegoosian approach with a vehemence that is hard to comprehend. Courts of today occasionally tolerate dice playing on the part of jurors, but only because the rules of evidence prohibit any examination of a jury's decisionmaking process. ${ }^{18}$ When judges engage in rolling the dice, however, they are universally condemned. ${ }^{19}$ The reasons for this rejection of dice playing by judges remain unclear. After all, the judicial process is supposed to be fair, and nothing is fairer than a crap game-assuming, of course, that all parties have sufficient opportunity to inspect the dice. ${ }^{20}$

Why does the prospect of deciding cases by dice make judges so uncomfortable? Random processes certainly are not unknown to the law. Most

15. I have just mentioned some of those "magic words" that entitle me to put a long footnote here citing all the articles by me and my friends that deal with legal indeterminacy (and belicve me, we've got plenty of them). My editor tells me, however, that a long footnote here will break up the "flow" of the Essay. So just write me, and I'll be happy to send you the list myself.

16. Françols Rabelais, Gargantua and PANTAGRuel 396-409 (J.M. Cohen trans., Penguin Books 1955) (1564).

17. Id. at 408.

18. See McDonald v. Pless, 238 U.S. 264, 267 (1915) (holding that while jurors should not determine verdict by lot, verdict may not be set aside based on juror's testimony as to her misconduct or that of her colleagues); Goins v. State, 21 N.E. 476, 482 (Ohio 1889) ("IA]nd thus it may appear to all the world. by the subsequent statements of the jurors, that the liberty of a citizen has been gambled away in a jury-room, yet the court is powerless to interfere, because the policy of the law is-First, to seclude the jury: and, second, not to allow their evidence to impeach their verdict."); see also FED. R. EVID. 606(b).

19. See Old Colony Bondholders v. New York, N.H. \& H.R. Co., 161 F.2d 413, 440 (2d Cir.) ("I1]f a trial judge who tried a juryless case-although he made special findings of fact which ordinarily. when supported by substantial evidence, would sustain his decision-were to reveal of record that his actual decisional process was that of Judge Bridlegoose, no appellate court would hesitate to reverse his judgment.") (citation omitted), cert. denied, 331 U.S. 858 (1947), and cert. denied, 331 U.S. 859 (1947); Knight v. County of Allegheny, 92 A.2d 225, $226 \mathrm{n}$.* (Pa. 1952) (finding judge's jury instruction reversible error because it "would seem to approximate the method employed by Rabelais' "Bridlegoose"").

The only practicing jurist with a good word to say for Judge Bridlegoose was Joseph C. Hutcheson. who, like other early Legal Realists, had funny ideas about how cases actually got decided. See Joseph C. Hutcheson, Jr., Lawyer's Law, and the Little, Small Dice, 7 TUL. L. Rev. 1, 12 (1932) ("IT]he power to draw in unprovided cases upon the divination of the 'little, small dice' is one of the glory points of the law which may never be surrendered ....").

20. But cf. FRANK LOESSER ET AL., GUYS AND DOLLS, act 4, sc. 3 (1951), reprinted in THE GUYS AND DOLLS BOOK (1982) (describing dice used by "businessman" Big Jule, who "had the spots removed for luck. But I remember where the spots formerly were."). 
jurisdictions assign judges and jurors to cases at random. In the Southern District of New York, as in most courts with more than one judge, the judge assigned to a new case supposedly is determined by a "wheel" that is spun at the time the new case is filed." So far as I know, however, no lawyer or litigant has ever watched the wheel being spun, or even observed it-a breach of gambling etiquette that would not be tolerated in even the seediest casino. 22

Of course, randomness in selecting the decisionmaker is unimportant if decisionmakers are fungible, that is, if all judges will decide like cases alike. Deciding the case by a roll of the dice, however, reintroduces an element that lawyers and judges have assiduously sought to banish from the legal process: the element of luck.

Luck, like spitting and swearing at the judge, is absolutely forbidden in a court of law. ${ }^{23}$ Litigants do not win because they are lucky. They win because they are "entitled" to relief. Lawyers do not win because they are lucky. They win because of their superior acumen and knowledge of the law. Nobody ever gets lucky in a court of law. Indeed, the very idea of introducing luck seems destructive to the smooth functioning of the legal system, which purports to be governed by rational and determinate processes. Yet, as we have seen, judges do not merely laugh off attempts to reach legal results through gambling or luck. Nor do they simply dismiss them as misguided efforts of foolish decisionmakers. They hate them and condemn them, and seek to suppress all discussion of such activities. ${ }^{24}$ One cannot help wondering if this is because almost every judge has, at least in some difficult case, felt the urge to go back into chambers and roll those little dice just once.

Contrast this stultifying and repressive attitude toward luck with the far more enlightened approach of baseball. In baseball, luck is permitted, even encouraged-and so, for that matter, are spitting and swearing at the judge. Luck is recognized as an essential element of the game, and its distribution among players and teams is carefully monitored and evaluated. There are hardluck pitchers and lucky hits, and various devices designed to maximize the

21. See Steven Brill, When the Government Goes Judge Shopping. Ast Law. Nov 1988, at 3 ("In the Southem District, as in all federal court districts with more than one or two judges. cases are assigned randomly. When a case is filed at the courthouse in Manhatun's Foley Square. a judge's name is picked. bingo-style, out of a bowl that spins on a whecl."): see also S.D.N.Y. R. FOR DIVISION OF BtSivesS AMONG DisTRICT JUDGES 4(b) ("All civil actions... shall be assigned by lot within each designated category to one judge for all purposes.").

22. Cf. NEV. REV. STAT. $\$ 463.670$ (1994) (authonzıng inspectuon of gaming devices). NJ REV STAT. \& 5:12-79 (1994) (same).

23. In a well-publicized incident in 1982, a tnal judge in Neu York chose between imposing a 20 or 30-day sentence by publicly flipping a coin while on the bench. He was censured by a commission of lawyers and judges and widely condemned by the legal communty. See E.R. Shipp. Friess is Barred from Ever Being New York Judge. N.Y. TIMES, Apr. 7. 1983. at B3. Conceming this incident. Professor Judith Resnik commented that "[t]he open embrace of chance as determinatwe was fnghtening." Judith Resnik. Tiers, 57 S. CAL. L. REV. 837, 841 (1984).

24. See supra notes 18-19. 23. 
quantum of luck available to a given team (e.g., rally caps). This, then, is the first respect in which baseball is demonstrably superior to law. The rules of baseball successfully acknowledge and incorporate the element of luck. The rules of law foolishly seek to suppress it.

Consider next the element of skill. While the normative structure of baseball acknowledges the importance of luck, it positively celebrates the skill and expertise of the game's great practitioners. Skill is the most important determinant of success in baseball, and the relative skills of various players are constantly assessed and compared, both through the market for free agents and through the statistical techniques for which the sport is famous. Indeed, many baseball statistics specifically measure the interrelationship between individual abilities and successful outcomes. A player knows not only how many hits he has compiled, but how many of those hits resulted in runs being scored. A pitcher knows how many "earned runs" he has given up, as well as how many games he has "won" or "lost"-as if the other players on the team were irrelevant. Finally, the rules of baseball recognize and readily assign blame to individual players for "errors" they commit, and acknowledge that even the best players occasionally make them.

The attitude of the legal system towards the skillfulness of its practitioners is far more problematic. Granted, there is some recognition that the skills of lawyers have an impact on case outcomes, as shown by the repeated calls for "skills training" in law schools, ${ }^{25}$ and by the autobiographical claims of celebrated attorneys, generally published long after the events in question, detailing how they "won" various highly publicized cases. Interestingly, unlike baseball, where only one pitcher receives credit for the "win" of any particular game, in law it seems possible, indeed common, for many lawyers to take credit for winning the same case. Sometimes, credit for the win may even be claimed by lawyers on opposite sides. ${ }^{26}$

Judicial opinions, however, invariably decline to acknowledge that the skill of the participants in a particular case had any significant impact on its outcome. One never reads that "this case was very close but plaintiff's lawyer pulled it out in the closing moments with a brilliant summation," nor that "counsel for plaintiff had a number of chances to score significantly on crossexamination, but failed to get the big hit." Judges still maintain the fiction that results spring syllogistically from the application of unproblematic facts to a

25. See Edward J. Devitt \& Helen P. Roland, Why Don't Law Schools Teach Law Students How To Try Lawsuits?, 13 WM. MrTCHELL L. REv. 445 (1987); see also Warren E. Burger, The Special Skills of Advocacy: Are Specialized Training and Certification of Advocates Essential to Our System of Justice?, 42 Fordham L. Rev. 227, 231 -33 (1973); Ronald L. Carlson, Competency and Professionalism in Modern Litigation: The Role of the Law Schools, 23 GA. L. REV. 689 (1989); Robert H. Jackson, Training the Trial Lawyer: A Neglected Area of Legal Education, 3 STAN. L. REV. 48, 57 (1950).

26. See, e.g., Larouche v. Kezer, 20 F.3d 68 (2d Cir. 1994) (rejecting claim by plaintiffs who obtained stay and injunction pending appeal but lost on all grounds on appeal, and who nonetheless sought attorney fees as "prevailing party"). 
preexisting body of law. Part of a lawyer's skill, therefore, is in concealing his skillfulness, making the case look easy and the result self-evident.

By the same token, legal decisions, unlike baseball, rarely acknowledge the role of lawyers' errors in contributing to the outcome of the contest. It is extremely difficult for a losing litigant to obtain reversal on the grounds that representation by counsel was inadequate. The relevant standard used to be that the representation must have been so incompetent as to "shock the conscience" of the court (and the average judicial conscience does not shock easily). While most courts have now purported to adopt a slightly more lenient standard, ${ }^{27}$ the fact remains that a lawyer's mistakes, like a lawyer's skills, almost never get proper credit in judicial decisions.

\section{ROUNDING SECOND: THE JURISPRUDENTIAL ANALYSIS OF BASEBALL RULES}

We have seen that baseball is clearly superior to law in that it recognizes the role played by luck and skill in producing results. But baseball, like law, is also a system of rules. Like legal rules, baseball rules are in part selfenforcing (i.e., players generally play by the rules) and in part subject to adjudication by expert decisionmakers (i.e., umpires). It is in considering and comparing the normative structures of baseball and law that American legal scholars have made their distinctive contribution. The following two sections describe the historical development of the branch of legal theory that attempts to bring sophisticated legal analysis to the study of baseball. I am pleased to note that up until now, this field has not been recognized as a separate area of jurisprudential thought. Accordingly, I get to make up the name for it. After studying the innovative nomenclature used by pioneers of other interdisciplinary legal studies (e.g., law and economics, law and literature), I have chosen to call this field "Iaw and baseball."

Most of the early work in the field of law and baseball started with the observation that the rules of baseball are less complex than the rules of law, but only a little less complex. Thus, legal theorists studied the rules of baseball in much the same way that neurologists study the nervous systems of worms, or behavioral psychologists teach rats to run through mazes. In each of these cases, researchers assume that their object of study is similar enough to their real interests to yield useful insights, but a little bit simpler and therefore, perhaps, a little bit easier to understand.

Thus, legal theorists studied the behavior of umpires in order to derive important insights about the nature of the adjudicative process. Consider the legendary discussion among three umpires as to the proper way to judge

27. See generally Project, Thirteenth Annual Revesw of Crmmul Procedure Unured States Supreme Court and Courts of Appeals 1982-1983, 72 GEO. L.J. 249. 529-36 (1983) 
whether pitches are balls or strikes. Says the first, "I call them as I see them." The second counters, "I call them as they are." The third responds, "they ain't nothing until I call them." Generations of American law students have pondered the Zen-like asperity of this story. ${ }^{28}$ It does encapsulate, in three lines, jurisprudential positions developed in other sources at far greater length, but with no increase in clarity.

The extent to which baseball umpires have discretion in calling balls and strikes and the degree to which they should exercise that discretion have been debated by legal theorists almost as much as by baseball players. (Unlike players, however, legal theorists generally do not risk being expelled from the game for the vigorous expression of their views. $)^{29}$

Improbably enough, the debate began with an Englishman, H.L.A. Hart, who developed the famous "scorer's discretion" argument, designed to show that even an unreviewed and unreviewable decisionmaker must score the game in accordance with the rules. Hart argued that in order for the scorer of a game to perform his role properly, he must award points in accordance with the underlying rules of the game. If the scorer were to award points some other way, Hart said, he would render the game incomprehensible, turning it into some new game called "scorer's discretion." 30 Hart never specified what game he actually had in mind, but it appears to be something like soccer or cricket, in which it is pretty easy to tell when a goal has been scored. ${ }^{31}$ We may wonder whether the course of jurisprudential theory would have been changed if Hart had been a fan of, say, ice skating, in which the relation between rules and scoring is far more problematic. ${ }^{32}$

Nonetheless, Hart's argument attempts to show that judges must follow the rules. But Hart allowed that when the rules are ambiguous, the law is indeterminate and the unreviewed decisionmaker must make a "choice between open alternatives." ${ }^{33}$ One person who found this argument troubling was a young American law professor named Ronald Dworkin. In responding to Hart's argument, Dworkin argued that rules only partially govern many legal determinations, and that "principles, policies, and other sorts of standards" also

28. One professor refers to the story as a "trope" of legal theory. Robert L. Birmingham, Teaching Contracts: Coming Home To Roost, 69 B.U. L. Rev. 435, 455 (1989) (reviewing P.S. ATIYAH, EsSAYS ON CONTRACT (1986)); see also John A. Miller, Indeterminacy, Complexity, and Fairness: Justifying Rule Simplification in the Law of Taxation, 68 WASH. L. REV. 1, 60-62 (1993) (analyzing contemporary positions on legal indeterminacy from perspective of ball/strike dichotomy).

29. But see Ruth Marcus, Clinton Withdraws Nomination of Guinier; Legal Writings Controversy Dooms Choice, WASH. POST, June 4, 1993, at AI.

30. H.L.A. HART, THE CONCEPT OF LAW 139-42 (1961).

31. I have been informed, although I have been unable to verify, that Hart was an avid cricket fan. If true, this casts considerable light on the scorer's discretion argument. Another way of stating Hart's point is that if the scorer did not score the game in accordance with the rules, "it wouldn't be cricket."

32. See, e.g., George Vecsey, Skate Junkie Confesses: 'Axel? Lutz?', N.Y. TıMEs, Feb. 27, 1994, \$ 8, at 1 ("D[on't] ask me about the judging. I don't understand it. Don't ask me about the scoring. I hated math when I was in school. Don't ask me about the jumps. I can't tell one from the other.").

33. HART, supra note 30 , at $123-24$. 
influence legal decisionmaking. ${ }^{34}$ For Hart, law was the supreme rule-based enterprise. He described law as constituted entirely by the interrelationship of primary and secondary rules. For Dworkin, however, there was another enterprise far more rule-bound and rule-dominated than law and that-you guessed it-was baseball.

Dworkin's early work characterizes baseball as an enterprise dominated by rules, and suggests that we take baseball rules as the model by which to judge legal rules. ${ }^{35}$ This suggestion, of course, has recently been taken up by Congress, which, at the urging of President Clinton and others, voted this summer to apply the rule of "three strikes and you're out" to federal criminal sentences. ${ }^{36}$ (By contrast, no one suggested that the length of the suspension of George Steinbrenner should be determined by the federal sentencing guidelines.) $)^{37}$

Dworkin found that some rules of law fit the model of baseball rules quite well (e.g., the statute of limitations for personal injury suits, "three years and you're out"). Other legal rules, however, seemed both more fundamental and more vague than the rules of baseball (e.g., the Erie doctrine, "three potentially applicable inconsistent rules of law and you're extremely confused"). Dworkin concluded that arguments based on vague and general principles are only appropriate in complex enterprises like law. ${ }^{38}$ He couldn't imagine, for example, a player arguing that he should be given four strikes on the general principle that it would make the game more interesting. ${ }^{39}$ In law, unlike baseball, Dworkin claimed, such arguments from general principles are made all the time, and are often used to resolve real controversies.

Sometime after Dworkin first made this point, however, I suspect someone told him about the infield fly rule. ${ }^{40}$ He may also have heard something about various quirks in the rules governing interference and balls that hit the roofs of domed stadiums. He may even have heard about the infamous "bonehead

34. RONALD DWORKIN. TAKING RIGHTS SERIOUSLY 22 (1978).

35. Id. at 24-25. ("This all-or-nothing is seen most plasnly if we look at the way rules operate, not in law, but in some enterprise they dominate-a game, for example. In baseball a rule provides that if the batter has had three strikes, he is out.").

36. See Violent Crime Control and Law Enforcement Act of 1994. Pub. L No 103-322. § 70001, 108 Stat. 1796, 1982.

37. But see Margaret A. Berger, Rethinking the Applicabilinv of Evdenttan Rules at Sentencing Of Relevant Conduct and Hearsay and the Need for an Infield Fly Rule. 5 FED. SEITENCISG REP 96 (1992) (arguing that federal evidentiary and sentencing rules create incentive for prosecutors to drop charges similar to incentive fielders had, prior to adoption of infield fly rule. 10 drop fly balls)

38. DWORKIN, supra note 34, at 26-27.

39. Major league owners of yore were apparently a bit more creative. In 1887, they did rase the number of strikes required for an out from three to four-presumably to make the game more interestung. See Bruce Handy, The Power of Three, N.Y. Times, Apr. 24, 1994. \& 6 (Magazune), at 108

40. For those not in the know, the infield fiy rule is designed to keep infielders from deliberately dropping fly balls when a player is on base in order to gel a double play. It provides thal, when an intielder could catch a fly ball for an out with ordinary effor, the batter is out whether or not the infielder stually catches the ball. On the rule's implications for law, see Berger, supra note 37; sourees cited infro notes $52-54$. 
Merkle" play. ${ }^{4 I}$ For whatever reason, in a later article Dworkin retreated from his claim that games only involve rules, not principles. Switching from baseball to chess, ${ }^{42}$ he argued that even the referee at a chess match may have to decide hard cases by relying on an underlying principle, such as the intellectual nature of the game, rather than simply by applying the rules. ${ }^{43}$ Clearly the same is true for a baseball umpire faced with a novel or unusual event during a game. Thus, rather than emphasizing the contrast between the rules of law and the rules of baseball, Dworkin set the stage for a new type of scholarship that would emphasize their similarities.

Unfortunately, Dworkin seems to have stopped writing about baseball altogether. In his recent work, he uses instead a new metaphor, comparing law to a chain novel written chapter by chapter by authors who have no other contact with each other. ${ }^{44}$ This obscure diversion seems likely to produce fewer counterexamples to his theoretical construct. Nonetheless, the potential indeterminacy of the rules of baseball continues to be a concern to the legal and philosophical community, as demonstrated by, among others, Kent Greenawalt's recent analysis of the metaphysical implications of the shrinking strike zone. ${ }^{45}$

\section{SAFE AT THIRD: THE DEVELOPMENT OF LAW AND BASEBALL STUDIES}

In the late 1970's and 1980's, radical movements appeared in the legal academy that challenged some of the most fundamental distinctions in legal

41. A favorite source of baseball jurisprudence, the bonchead Merkle play took place in the boltom of the ninth inning in a game between the New York Giants and the Chicago Cubs at the Polo Grounds. The score was tied, and the Giants had Fred Merkle on first and another man on third. The next batter hit safely and the man on third scored. The Cubs, however, claimed that Fred Merkle never touched second base during the play and that Johnny Evers, the Cubs' second baseman, had later tagged second. Unfortunately for the Cubs, the tag came only after Giants fans had begun pouring onto the field, and after the ball had been touched by at least one New York player. Merkle, moreover, insisted that he had touched second base on the way to the clubhouse. The umpire did not rule on the play prior to leaving the ficld. He later conveyed his view through a sportswriter that the game had ended in a tie. To make matters more confusing, a similar play had occurred a few weeks previously in a game between Chicago and Pittsburgh, in which there was no question that the man on first had failed to tag second. Nonetheless, the run was allowed. The umpire who made the call was the same one who disallowed the Giants' run in the bonehead Merkle game. The President of the National League let both calls stand. See generally Clancy \& Wciss, supra note 10 , at $421-24$.

42. The article was first published in 1975 , and may well have been written during or shortly after the highly publicized world chess championship match between Bobby Fischer and Boris Spassky in 1972.

43. DworkIN, supra note 34, at 102-04. Although part of the same book, many of the chapters in Taking Rights Seriously were reprinted from earlier law review articles. Id. at $\mathrm{xv}$.

44. RONALD DWORKIN, LAW'S EMPIRE 228-32 (1986). It might also be noted that the few modern instances of chain writing cited by Dworkin or his commentators (soap operas, mystery novels, and softcore pornography) do not constitute particularly distinguished literary genres. See James Boyle, Legal Fiction, 38 HASTINGS L.J. 1013, 1016 (1987); Anthony D'Amato, Can Any Legal Theory Constrain Any Judicial Decision?, 43 U. MIAMI L. REV. 513, 528 (1989).

45. Kent Greenawalt, How Law Can Be Determinate, 38 UCLA L. Rev. 1, 25 (1990). 
thought. ${ }^{46}$ Radical scholars questioned the validity of the distinction between "public" and "private," between "self" and "other," between "inside" and "outside," between "up" and "down," and, not least, between "law" and "baseball." They contended that the same reasoning and interpretive techniques that applied to legal cases and controversies also applied to baseball games. While some legal scholars were arguing that law could be found in all aspects of human relationships, these scholars were arguing that it could be found in the ballpark (where, not incidentally, they also serve beer).

In this, as in so many other areas of interdisciplinary legal studies, the work of Professor Robert Cover blazed the trail. In his groundbreaking 1979 op-ed piece in The New York Times, titled Your Law-Baseball Quiz," Cover explained that Oliver Wendell Holmes held a status in law similar to that of Casey Stengel in baseball, because both "had enormously varied and long careers" and "each achieved immortality for his use of the English language." Byron White, Cover felt, resembled Jackie Jensen, because "both were better as running backs."

Serious work comparing Supreme Court Justices and baseball players has continued apace. In 1983, Professor David Currie of the University of Chicago Law School sought to identify the least important Justice in Supreme Court history. ${ }^{48}$ His explanation for this endeavor makes it clear that he is a true follower of Robert Cover. As Currie notes:

I acknowledge at the outset the highly subjective nature of the inquiry. Insignificance, as every Chicago Cub supporter knows, is in the eye of the beholder. Yet every baseball town has its particular favorites: the shortstop who regularly threw the ball into the lower grandstand; the pitcher who habitually walked batters when the bases were loaded; the slugger who struck out whenever he came up with men on base. In hopes of identifying individuals of comparable stature in the judicial field, I have devised a set of Objective Indicators of Insignificance ("OII") . . . .99

Very recently, comparisons between baseball and Supreme Court judging became an issue of practical concern when it was widely speculated that Senator George Mitchell had withdrawn his name from consideration for a Supreme Court seat in order to remain eligible for the job of commissioner of

46. See, e.g., Pierre Schlag. Cannibal Moves: An Essay on the Metamorphoses of the Legal Distinction, 40 STAN. L. REV. 929 (1988); David L. Shapiro, The Death of the Up.Down Disunction, 36 STAN. L. REV. 465 (1984).

47. Robert M. Cover, Your Law-Baseball Quiz. N.Y. TMES. Apr. 5. 1979, at A23.

48. David P. Currie, The Most Insignificant Justice: A Preliminary Inqun, SO U. Cill. L. REV. 466 (1983).

49. Id. at 466. Incidentally. Currie's article itself deserves recognition for its unique acknowledgments footnote, which reads, "I should like to thank none of my colleagues for help in composing this semina! article. None of them appeared to take it seriously." Id. at $466 \mathrm{n}$.t. I must say that I can sympathize with Professor Currie's difficulties. 
major league baseball. ${ }^{50}$ It is not difficult to understand why Mitchell might have made such a choice. In many ways, the job of baseball commissioner is a cushier position than that of Supreme Court Justice. The pay is better and the off-season is longer. (The seats, however, are better on the Court.)

On the whole, though, Mitchell's choice points out how similar the two jobs really are. Both Supreme Court Justices and baseball commissioners serve as guardians of an important part of American culture and tradition. Both jobs confer great decisionmaking responsibility but no independent power of enforcement. The real difference, it seems to me, is that a successful baseball commissioner must achieve peaceful and harmonious working relations among twenty-eight owners and more than six hundred players. A successful Justice, on the other hand, must create a peaceful and harmonious consensus of opinion between Clarence Thomas and Ruth Bader Ginsburg. It is unclear whether Senator Mitchell sought the greater or the lesser challenge. ${ }^{5 t}$

While Cover and Currie investigated the parallel lives of Supreme Court Justices and baseball players, others probed the foundations of baseball jurisprudence itself. The legendary essay, Aside: The Common Law Origins of the Infield Fly Rule, ${ }^{52}$ appeared in the University of Pennsylvania Law Review in 1975. A steady stream of law review articles followed, with titles like Further Aside: A Comment on "The Common Law Origins of the Infield Fly Rule",53 The Infield Fly Rule and the Internal Revenue Code: An Even Further Aside, ${ }^{54}$ Strict Constructionism and the Strike Zone, ${ }^{55}$ and In re Brett: The Sticky Problem of Statutory Construction. ${ }^{56}$ These articles demonstrate what happens when finely honed skills of legal analysis and statutory interpretation are applied at extended and sometimes excruciating length to trivial or fanciful questions that have no effect on the real world. In short, these pieces are just like regular law review articles, only funnier. ${ }^{57}$

No discussion of baseball's contribution to contemporary American legal thought would be complete without some consideration of the strange jurisprudential career of Dennis Martinez. Martinez, a better-than-average

50. See Richard Justice, Baseball Has Eye on Mitchell; Seen as Front-Runner for Commissioner, WASH. POST, Apr. 13, 1994, at B1; Larry Whiteside, Mitchell Must Wait for Baseball Post, BostoN GLOBE, Apr. 14, 1994, at 43.

51. Mitchell himself has expressed a view on this subject. When the Senate majority leader was warned that as baseball commissioner he would have to deal with 28 big egos, he reportedly replied, "For me, that's a 72 percent reduction." Bob Curran, Find the Missing Hockey Fans, BufFalo News, May 11 , 1994 , at 15.

52. Aside, The Common Law Origins of the Infield Fly Rule, 123 U. PA. L. REv. 1474 (1975).

53. John J. Flynn, Further Aside: A Comment on "The Common Law Origins of the Infield Fly Rule", 4 J. CONTEMP. L. 241 (1978).

54. Mark W. Cochran, The Infield Fly Rule and the Internal Revenue Code: An Even Further Aside, 29 WM. \& MARY L. REV. 567 (1988).

55. Douglas O. Linder, Strict Constructionism and the Strike Zone, 56 UMKC L. REV. 117 (1987).

56. Finkelstein, supra note 10.

57. See also Donald A. Winslow \& Seth C. Anderson, From "Shoeless" Joe Jackson to Ivan Boesky: A Sporting Response to Law and Economics Criticism of the Regulation of Insider Trading. $81 \mathrm{KY}$. L.J. 295 (1993) (not as funny as the other articles, but, then again, it deals with law and economics). 
pitcher then playing for the Baltimore Orioles, was engaged in some fairly standard pregame colloquy with Ira Berkow, a sports columnist for The New York Times. Berkow had just seen Martinez talking to his manager, Earl Weaver, and asked Martinez to recount the conversation. Martinez replied that the manager had told him to "throw strikes and keep 'em off the bases." Martinez further commented, "[w] hat more could he say?" 58 Unbeknownst to Martinez, his remarks subsequently were to be noted by Stanley Fish, an eminent legal and literary theorist, who detected in them the aspect of genius. $^{59}$

Now it must be pointed out that baseball has had more than its share of great literary figures, most of whom worked in the oral tradition. Nonetheless, the sayings of such men as Casey Stengel, Satchel Paige, Phil Rizzuto, and Yogi Berra are widely quoted and remembered, and have even found their way into more than a few judicial opinions. A recent LEXIS search found thirty citations to the wit and wisdom of Berra. The phrase most commonly attributed to him, "it's déjà vu all over again," appears particularly helpful to courts with respect to issues such as stare decisis and res judicata."

When considered against these masters of the baseball koan, "throw strikes and keep 'em off the bases" seems pretly weak tea indeed. But that, of course, was Fish's point. Fish, as a good postmodern literary theorist, had abandoned the canon of classical baseball literary tradition. Like other postmodern critics, he offered us the banal and pedestrian remark as an equivalent to the clever and witty one. He applauded Martinez precisely because Martinez had nothing interesting to say about what he did. The only interesting thing was that he did it.

Fish found this professional taciturnity important because it allowed him to argue that lawyers, like baseball players, have nothing interesting to say about what they do, and therefore, like Dennis Martinez, they should just shut up and do it. ${ }^{61}$ Like the law and baseball radicals. Fish believed that law and baseball are basically the same game; lawyers just talk about it too much.

Of course, Fish's hope that he could get lawyers to shut up by publishing a twenty-seven-page article in The Yale Law Journal never was very realistic.

58. Ira Berkow, The Old and New Manager. N.Y. TIMIES. June 26. 1985. at B13

59. See Stanley Fish. Dennts Martunez and the Uses of Theorv. 96 YAl.E L.J 1773 (1987)

60. See, e.g., Key v. Sullivan, 925 F.2d 1056, 1061 (7th Cir. 1991): see alsa Nawonal Rifle Ass'n 、 Federal Election Comm'n, 854 F.2d 1330. 1336 (D.C. Cir. 1988); United States 、 Mann, 810 F 2d 80. 81 (6th Cir. 1987); Davis v. Coopers \& Lybrand. 787 F Supp 787. 804 n 41 (ND lil 1992). Claussen v. Aetna Casuaity \& Sur. Co., 754 F. Supp. 1576. 1577 (S.D. Ga. 1990); United Stales I Datenpon, 740 F. Supp. 1371, 1372 (S.D. Ind. 1990); Parsons v. Parsons. 490 N.W 2d 733.739 (S D 1992) (Sabers. J . dissenting).

61. Interestingly, in the column that started the whole business. Ira Berhow dixagreed with the Martinez (and Fish) position that Weaver had said all that could be said on the matter After recounting the conversation, he commented that "Weaver didn't say quite enough, apparently The Yankees beat the Orioles, 5-4. But there were still nearly 100 games left and Weaver. surely. will think of other things to say." Berkow, supra note 58, at B13. 
His article engendered more articles, and more talk, by yet more lawyers. (To my knowledge, no baseball players have yet responded.) Some of this response was about law or legal theory, but a substantial amount was about baseball. In order to refute Fish, lawyers analyzed baseball talk, ${ }^{62}$ and baseball books and baseball movies, ${ }^{63}$ and Ted Williams' swing, ${ }^{64}$ and why Orel Hershiser is a better pitcher than Dennis Martinez. ${ }^{65}$ Indeed, the most significant thing about this affair is the way that Fish's invocation of some fairly ordinary baseball dialogue sparked a massive debate among legal theorists. It is hard to imagine that Fish would have gotten the same response if he had started with, say, a quote from Justice Cardozo.

The lessons from the Martinez-Fish enterprise seem to me to be twofold: first, that baseball is simply more interesting than law, and second, that it is impossible to get lawyers to shut up about either subject.

\section{THROWN OUT AT HOME: CRITIQUES OF LAW-BASEBALl SCHOLARSHIP}

We have seen, therefore, how the development of law and baseball scholarship has revealed insights that, if not superior to those of prior legal scholars, are at least different. But law and baseball scholarship itself is not immune from critique. Before I close this Essay, I feel I must say something both about potential feminist challenges to law and baseball studies and about the insidious dangers of game theory.

The fact that few women have achieved positions of power or prominence in the field of baseball may lead to some resistance to the law and baseball movement. ${ }^{66}$ While a flip answer might be that, until a very few years ago, the same observation could have been made about law, it seems to me that the feminist challenge goes deeper than that.

There are, in fact, two major strands of contemporary feminist thought, each of which has important implications for law and baseball scholarship. Those who are inclined to the "other voice" approach seek to discover the female aspects of institutions that, in a male-dominated world, have been

62. See Pierre Schlag, Fish v. Zapp: The Case of the Relatively Autonomous Self, 76 GEO. L.J. 37. 53-54 (1987) (suggesting pitching advice that Wittgenstein, Hegel, and Kant might have given to Dennis Martinez).

63. See Brook Thomas, Stanley Fish and the Uses of Baseball: The Return of the Natural, 2 YALE J.L. \& HumaN. 59 (1990); Steven L. Winter, Bull Durham and the Uses of Theory, 42 STAN. L. REv. 639 (1990).

64. See Michael S. Moore, The Interpretive Turn in Modern Theory: A Turn for the Worse?, 41 STAN. L. REV. 871,916 (1989) (suggesting that it is worth imitating).

65. See Margaret J. Radin, Reconsidering the Rule of Law, 69 B.U. L. REv. 781, 802 (1989) (noting that Hershiser pays more attention to baseball "theory").

66. There are some notable exceptions in the sport's management, including the late Jean Yawkey, the much-beloved owner of the Boston Red Sox, and Marge Schott, the somewhat less-beloved owner of the Cincinnati Reds. For the contribution of women players on the field at a moment of national crisis, sce A LeAGUe of TheIR OWN (Columbia Pictures 1992). 
suppressed and driven underground. Such scholars could make much of the fact that baseball, as its historians now generally recognize, was not invented by Abner Doubleday, but rather is the outgrowth of the British game of "rounders," by schoolgirls. ${ }^{68}$ It is also worth noting that the first known literary reference to "base-ball" appears in Jane Austen's novel Northanger Abbey, in reference to a fifteen-year-old girl who prefers cricket and baseball to reading books. ${ }^{69}$ These little-known facts strongly suggest that the time is overdue for an account of baseball that looks beyond its masculinist obsession with winning and domination and its objectifying emphasis on statistics, and discovers instead its hidden feminist face.

I myself, however, am inclined to the more radical feminist approach. The notion that baseball is inherently a male game is itself a product of socially constructed masculinist thinking, and not a reflection of innate physical ability. Indeed, although many may view this as an extreme position, I would maintain that women, with the proper experience and training, can be equal, and perhaps even superior, to men in their ability to sit on the couch, drink beer, and make wisecracks about the game. Moreover, for those concerned with breaking down hegemonic constructs in the legal academy, law and baseball scholarship offers the advantage that there has been virtually no participation in it by dead white European males.

But there is a specter haunting law-baseball scholarship, a new interdisciplinary approach that threatens to replace the playful analogizing of the law-baseball aficionados with the soulless rigidity of mathematical analysis. I am talking about game theory. Now I will concede that game theory can provide important heuristics for analyzing certain types of legal problems, and that it is often superior to the economic models it replaces. It would be extremely unfortunate, however, for all comparisons of legal rules and baseball rules to be subsumed under the formal strictures of game theoretic analysis.

It's not the mathematical approach that is objectionable. Everyone knows that baseball fans love math (or at least statistics, which look like math to everyone but mathematicians). The beauty of statistical analysis in baseball, however, is that you can use it to prove anything you want. Through careful use of the appropriate stats, unknown players can be shown to have performed extraordinary feats, and great players can be shown to have been merely average. Because all these positions are supportable, every one of them is open

67. See, e.g.. Fox Butterfield, Cooperstown? Hoboken' Try New York Cin. N Y Tmes. Oet. 4. 1990. at $\mathrm{Al}$.

68. See Googlies Make Way For Bloopers. THE HERALD (Glasgow), June 30. 1993, at 12. Colin F Hartis, A Real. World Sport. OTTAWA CITIZEN, Nov. 7. 1992, at G6: Ken Lawrence. BBC Pitching for Baseball, THE TIMES (London), Dec. 21, 1991, at 28; Ben Wnght \& Jason Steger. Sniff Of Scandal Hus Super-Rich Sluggers, FINANCIAL TIMES (London), May 9. 1987. al 17.

69. Jane Austen, Northanger Abbey 13 (John Davie ed.. Oxford Unuversity Press 1971) (1848), see also 1 OXFORD ENGLISH DICTIONARY 979 (2d ed. 1989). 
to (endless) debate. Game theory, in contrast, seeks to determine "dominant strategies" leading to stable equilibria and therefore predictable outcomes. I leave it to the reader to decide which mathematical approach provides greater insight into the legal process (or baseball).

Moreover, the basic purpose of baseball statistics is to reanalyze and shed new light on games that have already been played. The basic purpose of game theory is to invent new games that are analytically precise, have determinate outcomes, and are no fun to play. This, of course, is baseball's big advantage. It is hard to imagine anyone, even a law and economics professor, sitting down in front of the TV with a beer to watch a close game of "prisoner's dilemma." Law-baseball scholarship, on the other hand, empowers those law students (and professors) who wish to defer studying and other legal drudgery by giving them an excuse to watch the World Series. It's not the only form of legal research that causes you to work late nights and weekends. But it may be the only one that gives you reason to cheer while you're doing it. 